\title{
Study of Bond Properties of Steel Rebars with Recycled Aggregate Concrete. Experimental Testing
}

\author{
M. M. Rafi \\ Department of Earthquake Engineering, NED University of Engineering and Technology, Karachi, \\ Pakistan \\ rafi-m@neduet.edu.pk \\ УДК 539.4

\section{Экспериментальное исследование адгезионных свойств железобетонных изделий с добавками повторно утилизированного бетона}

\section{М. М. Рафи}

Университет инженерии и технологии NED, Карачи, Пакистан

Переработка бетона является одним из эффективных решений проблемы утилизации строительных отходов. Исследуется изменение адгезионных напряжений на стыке стальных арматурных стержей с матрицей из переработанного бетона в зависимости от величины проскальзывания между ними. Адгезионные испытания на растяжение проводились на концентрических образцах. Образцы с наполнителем из стандартного бетона использовались в качестве контрольных. Исследовались арматурные стержни двух типов (горячекатаные деформированные и холоднокрученные ребристье) с разными диаметрами и разной долей добавки переработанного бетона. Длина заделки стержней пятикратно превышала их диаметр. Стержни диаметром 12 мм имели наивысшую прочность межфазного сиепления/ адгезии, которая уменьшалась с увеличением их диаметра. Величина доли добавки переработанного бетона практически не влияла на адгезионную прочность стержней. При этом реакиия холоднокрученных ребристых стержней по достижении пика адгезионных напряжений в зависимости от проскальзывания оказалась более жесткой, чем горячекатаных деформированных стержней.

Ключевые слова: агрегатное состояние, адгезия, прочность при сжатии, разрушение, испытания на растяжение, армирование, напряжение сдвига.

\section{Not ation}

$\tau_{\max }-$ maximum interfacial bond stress

$c \quad-$ concrete cover

$c_{0} \quad-$ clear distance between the ribs of the reinforcing bar

$d_{b} \quad-$ diameter of bar

$f_{c} \quad-$ concrete compressive strength

$l_{d} \quad-$ rebar embedment length

$s_{\max }-$ maximum rebar slip

CSA - crushed stone aggregates

RAC - recycled aggregate concrete

RCA - recycled concrete aggregates

SD - standard deviation 
Introduction. Concrete is one of the popular construction materials around the world and is employed in both structural and non-structural applications. Goldstein [1] estimated that one ton of concrete is produced annually for each person on earth. Nonetheless, not all concrete, which is produced during the construction, renovation and demolition (CRD) activities, is fully utilized. As a result, large amount of concrete waste is generated in addition to other waste materials. The disposal of CRD waste is considered as one of the challenges in big cities [2-4]; this waste is most often utilized in landfilling application.

Most of the CRD waste comprises of concrete which is about $75 \%$ by weight of all building materials [5]; this concrete has, therefore, become a burdening waste [6,7]. Recycling of concrete has attracted attention of the researchers around the world in an attempt to solve the problem of waste concrete [8-14]. The use of recycled aggregates (RA) as a substitute of natural aggregates may reduce burden on natural deposits in addition to solving the waste management problem.

Use of recycled aggregates in structural concrete has so far received lesser attention of the researchers. Adequate bond between steel and concrete is considered as the most important aspect in reinforced concrete $(\mathrm{RC})$ design. It allows transfer of stresses to the steel rebars and influences the performance of RC in terms of crack width, deflection, plastic hinge rotation capacity, strength of end anchorages and energy dissipation. This paper presents the result of studies which were conducted to investigate the bond behavior of steel bars embedded in concrete made with RA, termed as recycled aggregate concrete (RAC). Pullout tests were carried out to study the rebar bond strength loaded in tension. Parameters of the study included rebar type and diameter, and level of replacement of recycled concrete aggregates (RCA) keeping the rest of all factors the same. Different combinations of RCA and natural crushed stone aggregates (CSA) were tried in RAC. The bond stress-slip response of the steel bars with RAC was compared with the control specimens, which were made with CSA concrete.

1. Background and Scope. Concrete is a weak material in tension and is reinforced with steel bars to enable it to resist tensile stresses. Adequate bond between steel and concrete is required for safe transference of forces to the steel bars. Friction and adhesion are the two important factors which are responsible for providing strength to the steelconcrete interface bond. Therefore, the properties of both the steel and concrete can influence the bond. The interfacial bond stress $(\tau)$ is proportional to the normal confining pressure which is exerted on the bar by concrete cover and transverse reinforcement. The higher the normal pressure, the higher the frictional force required for pullout [15]. As a result, the bond strength is increased. $\tau$ is calculated with Eq. (1) which is the average stress assuming constant tangential stress along the embedded rebar:

$$
\tau=\frac{P}{\pi d_{b} l_{d}}
$$

where $P$ is the load $d_{b}$ is the diameter of bar, and $l_{d}$ is the embedment length.

Two types of round reinforcing bars are produced in Pakistan [16]. These include cold-twisted ribbed and hot-rolled deformed bars. The former type has oblique indentations and is manufactured in accordance with BS 4449 [17] by cold working of an ordinary grade of steel in which the round bar is subjected to a simultaneous cold rolling and cold ribbing. The usual method of cold working of reinforcing rebars involves stretching and twisting of mild steel between two fixed chucks. These bars are usually available with the trade name of TOR bars. The hot-rolled deformed bars are manufactured by re-rolling of high strength billet in accordance with ASTM A615 [18]. Both the longitudinal and circumferential indentations are provided on these bars which are generally considered of superior quality compared to the cold-twisted ribbed bars. Figure 1 illustrates typical stress-strain curves 


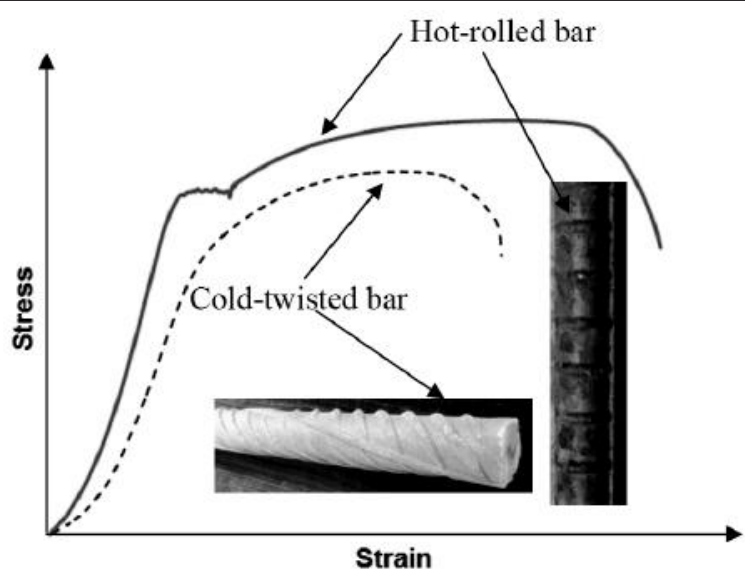

Fig. 1. Typical stress-strain curves of bars.

both for hot-rolled deformed and cold-twisted ribbed bars available in Pakistan. It is noted in Fig. 1 that while the former bar curve exhibits typical characteristics expected of steel reinforcing rebar it is hard to identify the yield point on the latter bar curve. Similarly, the cold-twisted ribbed bar has a small strain hardening zone compared to the hot-rolled deformed bar. Nonetheless, the cold-twisted ribbed bars are also demanded by the local construction industry due to their lower prices, as compared to the hot-rolled deformed bars. Both these bars have been employed in this study.

The studies related to performance of structural members made with RAC are limited [19-26]. Satisfactory bond behavior is essential for the performance of an RC structure. This behavior can be studied by carrying out pullout tests on steel bars embedded in concrete specimens. The available research indicates that these tests can provide reliable estimates of the bond efficiency of deformed reinforcing bars [27, 28]. While different aspects of RC made with RAC have been investigated by the researchers [20-26], there have been limited studies in the technical literature on the investigation of its bond behavior with steel bars [28-34].

A review of the aforementioned studies indicates several gaps. For example, Prince and Singh [28, 34] employed 8, 10 and $12 \mathrm{~mm}$-diameter bars, which are normally required for stirrups. As a result, the results of the study may not apply to the bars required for flexure. The study conducted by Kim and Yun [32] employed 16 mm-diameter bars, which were non-conforming to ASTM A615 [18] as the yield strength $\left(f_{y}\right)$ of these bars was $383 \mathrm{MPa}$. Xiao and Falkner [30] used $10 \mathrm{~mm}$-diameter bar with 50 percent and 100 percent RCA replacement. Not only that this diameter bar is suitable only for stirrups (as mentioned in the above), the acceptance of such high replacement ratios of RCA in structural concrete will be difficult by the regulatory authorities. As a result, the results of the above study may not be used in design applications. Butler et al. [31] employed 25 mm-diameter bars; no information, however, was provided on the properties of the bars. Finally, Lima et al. [33] used $10 \mathrm{~mm}$-diameter bars for the pullout specimens, which were casted using 30,60, and 100 percent levels of replacement of RCA. Similar to the aforementioned studies, the major shortcomings of this study include high level of RCA replacement, bar size which is not suitable for longitudinal reinforcement and unavailability of steel bar properties. The study presented in this paper is an attempt to fill these identified gaps by considering a wide range of variables. Pullout test specimens were employed to study the bond behavior of steel bars with the normal strength RAC made from ordinary Portland cement. The test program included three levels of RCA replacement, different bar diameter, and both the cold-twisted ribbed and hot-rolled deformed bars. The embedment length of the bar was 
taken as $5 d_{b}$. The selection of this embedment length is attributed to the fact that for short $l_{d}$, a uniform distribution of $\tau$ along the embedded surface can be assumed [29, 35], which can be calculated by Eq. (1). Other embedment lengths, cement types, bar types, RCA replacement levels and splitting tests are beyond the scope of this study. Similarly, economic and durability aspects of RAC are not considered.

\section{Experimental.}

\subsection{Materials.}

2.1.1. Aggregates. Two types of coarse aggregates were employed in this study: CSA and RCA. CSA and fine aggregates (sand) were purchased from a local supplier. The recycled aggregates were obtained from the concrete waste which was generated from the commercial testing of concrete specimens in the Material Testing Laboratory of the Department of Civil Engineering at NED University. Note that the employed waste is of unknown origin, quality and/or composition as these specimens were sent in the laboratory for testing by the local construction industry. This could be regarded as an important aspect in the perspective of practical use of RA in structural concrete. The aggregates were sieved using sieves of required sizes and were blended in the proportion to provide grading similar to CSA. Tests on aggregates were carried out in accordance with the relevant ASTM standards to determine their properties. A summary of the test results is given in Table 1. It can be noted in Table 1 that the specific gravity and density of CSA is higher than RCA, whereas impact values, LA abrasion and absorption of the latter are significantly higher than those of the former aggregates. This could be attributed to the presence of cement-sand mortar in RCA, which is lightweight and porous.

$\mathrm{T}$ a b 1 e 1

Properties of Aggregates

\begin{tabular}{||l|c|c|c|c||}
\hline \multicolumn{1}{|c|}{ Property } & Standard & CSA & RCA & Sand \\
\hline Bulk specific gravity & $\begin{array}{c}\text { ASTM C127/C128* } \\
\text { (ASTM 2001a,b) [36, 37] }\end{array}$ & 2.67 & 2.38 & 2.65 \\
\hline Absorption (\%) & $\begin{array}{c}\text { ASTM C127/C128* } \\
\text { (ASTM 2001a,b) [36, 37] }\end{array}$ & 0.67 & 5.13 & 2.3 \\
\hline Loose density (g/cc) & ASTM C29 (ASTM 1997) [38] & 1.6 & 1.33 & 2.08 \\
\hline Dry rodded density (g/cc) & ASTM C29 (ASTM 1997) [38] & 1.83 & 1.53 & 2.18 \\
\hline Fineness modulus & ASTM C136 (ASTM 2001) [39] & - & - & 2.86 \\
\hline Impact (\%) & ASTM C131 (ASTM 2014) [40] & 7.05 & 28.49 & - \\
\hline L. A. abrasion (\%) & ASTM C131 (ASTM 2014) [40] & 27.21 & 34.70 & - \\
\hline
\end{tabular}

* ASTM C128 for sand.

The sieve analyses for both fine and coarse aggregates (RCA and CSA) were performed, in accordance with ASTM C-136 [39]; both aggregate types complied with the requirements of ASTM C33 [41]. The fineness modulus of sand is given in Table 1.

2.1.2. Cement. Ordinary Portland cement (OPC) was employed in this study. The cement, which complied with ASTM C150 [42], was purchased from a local supplier.

2.1.3. Steel Rebars. Two types of steel rebars were employed in the test program, as mentioned earlier. These include hot-rolled deformed and cold twisted ribbed bars. The bars of diameter 12, 16, and $20 \mathrm{~mm}$ were employed. The steel bar properties are given in Table 2, which were determined by carrying out tensile tests on the bars in the laboratory, in accordance with ASTM E8/E8M [43]. 
T a b 1 e 2

Tensile Properties of Steel Bars

\begin{tabular}{|c|c|c|c|c|c|c|c||}
\hline \hline Bar type & $\begin{array}{c}\text { Bar } \\
\text { diameter } \\
(\mathrm{mm})\end{array}$ & $\begin{array}{c}\text { Rib } \\
\text { spacing } \\
(\mathrm{mm})\end{array}$ & $\begin{array}{c}\text { Rib } \\
\text { height } \\
(\mathrm{mm})\end{array}$ & $\begin{array}{c}\text { Elastic } \\
\text { modulus } \\
(\mathrm{GPa})\end{array}$ & $\begin{array}{c}\text { Yield } \\
\text { strength } \\
(\mathrm{MPa})\end{array}$ & $\begin{array}{c}\text { Ultimate } \\
\text { strength } \\
(\mathrm{MPa})\end{array}$ & $\begin{array}{c}\text { Strain } \\
\text { at yielding } \\
(\%)\end{array}$ \\
\hline \multirow{2}{*}{$\begin{array}{c}\text { Cold- } \\
\text { twisted } \\
\text { ribbed }\end{array}$} & 12 & 7.2 & 0.83 & 207 & 439 & 549 & 0.21 \\
\cline { 2 - 9 } & 16 & 8.9 & 1.10 & 203 & 420 & 488 & 0.21 \\
\hline \multirow{2}{*}{$\begin{array}{c}\text { Hot-rolled } \\
\text { deformed }\end{array}$} & 12 & 9.7 & 1.10 & 206 & 423 & 495 & 0.21 \\
\cline { 2 - 9 } & 16 & 8.2 & 0.83 & 203 & 461 & 623 & 0.23 \\
\cline { 2 - 9 } & 20 & 9.7 & 1.10 & 204 & 523 & 595 & 0.26 \\
\hline
\end{tabular}

As mentioned before, the embedment length of bar was taken as $5 d_{b}$; embedment lengths $\left(l_{d}\right)$ of 60,80 , and $100 \mathrm{~mm}$ were used, respectively, for 12,16 , and $20 \mathrm{~mm}$ diameter bars. The remaining length of the bar was debonded using three layers of plastic tape applied over a layer of polythene sheet.

2.2. Specimen Details. Pullout test specimens of $200 \mathrm{~mm}$ cubes were cast, in accordance with RILEM technical recommendations [44]. The target 28-day concrete compressive strength $\left(f_{c}\right)$ was taken as $21 \mathrm{MPa}$ and the mix design procedure was carried out in accordance with ACI 211.1-91 [45] using a water/cement ratio of 0.5. The concrete mix used is described in Table 3. Based on some trial and error calculations, the amount of cement with each of the aforementioned level of RCA replacement was arbitrarily increased by $5 \mathrm{~kg} / \mathrm{m}^{3}$, in order to keep the concrete slump and $f_{c}$ nearly the same for all mixes (Table 3). Cylinders of $100 \times 200 \mathrm{~mm}$ size were cast to determine the concrete strength in compression and tension. Splitting tests were conducted to determine the concrete tensile strength. The concrete type in Table 3 was designated based on percent replacement of RCA.

T a b 1 e 3

Details of Concrete Mixes

\begin{tabular}{|c|c|c|c|c|c|c||}
\hline $\begin{array}{c}\text { Concrete } \\
\text { type }\end{array}$ & $\begin{array}{c}\text { Cement } \\
\left(\mathrm{kg} / \mathrm{m}^{3}\right)\end{array}$ & $\begin{array}{c}\text { Sand } \\
\left(\mathrm{kg} / \mathrm{m}^{3}\right)\end{array}$ & $\begin{array}{c}\text { Coarse } \\
\text { aggregate } \\
\left(\mathrm{kg} / \mathrm{m}^{3}\right)\end{array}$ & $\begin{array}{c}\text { Slump } \\
(\mathrm{mm})\end{array}$ & $\begin{array}{c}28 \text {-day } \\
\text { strength } \\
(\mathrm{MPa})\end{array}$ & $\begin{array}{c}\text { Splitting } \\
\text { tensile strength } \\
(\mathrm{MPa})\end{array}$ \\
\hline $0 \% \mathrm{RAC}$ & 315 & 791 & 1135 & 45 & 23 & 2.10 \\
\hline $10 \% \mathrm{RAC}$ & 320 & 791 & 1135 & 45 & 26 & 2.80 \\
\hline $20 \% \mathrm{RAC}$ & 325 & 791 & 1116 & 50 & 26 & 2.85 \\
\hline $30 \% \mathrm{RAC}$ & 330 & 791 & 1116 & 40 & 25 & 2.17 \\
\hline
\end{tabular}

Mixing of concrete was performed using a mixer. The maximum aggregate size was $12 \mathrm{~mm}$. Potable tap water was mixed in the concrete and the exact amount of water varied depending on the moisture contents of aggregates. The slump of concrete ranged from 40 to $50 \mathrm{~mm}$; it was measured at each casting of batch and is given in Table 3 . The bars were cast keeping them in the center of the cube with the aforementioned embedment lengths. The concrete in the steel mold was vibrated using a mechanical vibrator of shaft diameter $16 \mathrm{~mm}$. 
The concrete specimens were removed from the mold after 24 hours and were cured in a water tank for 28 days. The 28-day compressive and splitting tensile strengths of concrete are given in Table 3 for all the mix types which is an average of 3 cylinders each. It is seen in Table 3 that the 28-day strength for all mix types is close to each other. The specimens were moved in the laboratory environment at the end of curing period and were kept there until testing. The testing of specimens started after 28 days and was completed in nearly one and a half month.

A total of 72 pullout specimens were cast and tested for the test program. The details of these specimens are given in Table 4. The notation of the specimen is as follows: the first two numbers indicate percentage of RCA replacement, the second letter $(\mathrm{P})$ represents a pullout specimen, this is followed by the bar diameter and the letter in the end is the type of bar, such as $\mathrm{D}$ for hot-rolled deformed and $\mathrm{T}$ for cold-twisted ribbed bar. For example, $10 \mathrm{P} 12 \mathrm{~T}$ is a pullout specimen made with 10 percent replacement of RCA with a coldtwisted ribbed bar of $12 \mathrm{~mm}$-diameter.

$\mathrm{T}$ a b 1 e 4

Details of Pullout Specimens

\begin{tabular}{|c|c|c|c|c|c|c|c|c|}
\hline \multirow[t]{2}{*}{ Specimen } & \multirow[t]{2}{*}{ Nos. } & \multirow[t]{2}{*}{ Bar type } & \multirow{2}{*}{$\begin{array}{c}l_{d} \\
(\mathrm{~mm})\end{array}$} & \multicolumn{2}{|c|}{$f_{c}(\mathrm{MPa})$} & \multirow{2}{*}{$\begin{array}{c}\tau_{\max } \\
(\mathrm{MPa})\end{array}$} & \multirow{2}{*}{$\frac{\tau_{\max }}{\sqrt{f_{c}}}$} & \multirow{2}{*}{$\begin{array}{c}\text { Bond } \\
\text { ratio }\end{array}$} \\
\hline & & & & Mean & SD & & & \\
\hline 0P12D & 3 & Hot-rolled & 60 & 24.09 & 0.46 & 24.36 & 4.96 & 1.00 \\
\hline 10P12D & 3 & Hot-rolled & 60 & 26.73 & 1.17 & 23.82 & 4.61 & 0.93 \\
\hline 20P12D & 3 & Hot-rolled & 60 & 25.81 & 0.59 & 24.04 & 4.73 & 0.95 \\
\hline $30 \mathrm{P} 12 \mathrm{D}$ & 3 & Hot-rolled & 60 & 30.12 & 1.60 & 26.27 & 4.79 & 0.97 \\
\hline 0P16D & 3 & Hot-rolled & 80 & 24.09 & 0.46 & 20.93 & 4.26 & 1.00 \\
\hline 10P16D & 3 & Hot-rolled & 80 & 28.54 & 1.29 & 21.69 & 4.06 & 0.95 \\
\hline 20P16D & 3 & Hot-rolled & 80 & 25.81 & 0.59 & 19.67 & 3.87 & 0.91 \\
\hline 30P16D & 3 & Hot-rolled & 80 & 31.82 & 0.64 & 17.34 & 3.59 & 0.84 \\
\hline 0P20D & 3 & Hot-rolled & 100 & 21.64 & 0.54 & 20.10 & 4.32 & 1.00 \\
\hline 10P20D & 3 & Hot-rolled & 100 & 26.73 & 1.17 & 19.23 & 3.72 & 0.86 \\
\hline 20P20D & 3 & Hot-rolled & 100 & 33.09 & 1.27 & 21.59 & 3.75 & 0.87 \\
\hline $30 \mathrm{P} 20 \mathrm{D}$ & 3 & Hot-rolled & 100 & 31.82 & 0.64 & 19.28 & 3.42 & 0.80 \\
\hline $0 \mathrm{P} 12 \mathrm{~T}$ & 3 & Cold-twisted & 60 & 21.64 & 0.54 & 23.70 & 5.09 & 1.00 \\
\hline $10 \mathrm{P} 12 \mathrm{~T}$ & 3 & Cold-twisted & 60 & 28.54 & 1.29 & 26.32 & 4.08 & 0.80 \\
\hline $20 \mathrm{P} 12 \mathrm{~T}$ & 3 & Cold-twisted & 60 & 25.81 & 0.59 & 21.84 & 4.13 & 0.81 \\
\hline $30 \mathrm{P} 12 \mathrm{~T}$ & 3 & Cold-twisted & 60 & 30.12 & 1.60 & 25.16 & 4.58 & 0.90 \\
\hline 0P16T & 3 & Cold-twisted & 80 & 24.09 & 0.46 & 22.14 & 4.51 & 1.00 \\
\hline 10P16T & 3 & Cold-twisted & 80 & 28.54 & 1.29 & 22.37 & 4.19 & 0.93 \\
\hline 20P16T & 3 & Cold-twisted & 80 & 33.09 & 1.27 & 22.95 & 3.99 & 0.88 \\
\hline $30 \mathrm{P} 16 \mathrm{~T}$ & 3 & Cold-twisted & 80 & 30.12 & 1.60 & 22.23 & 4.05 & 0.90 \\
\hline 0P20T & 3 & Cold-twisted & 100 & 21.64 & 0.54 & 21.11 & 4.54 & 1.00 \\
\hline 10P20T & 3 & Cold-twisted & 100 & 26.73 & 1.17 & 19.23 & 4.22 & 0.93 \\
\hline 20P20T & 3 & Cold-twisted & 100 & 33.09 & 1.27 & 22.14 & 3.85 & 0.85 \\
\hline $30 \mathrm{P} 20 \mathrm{~T}$ & 3 & Cold-twisted & 100 & 31.82 & 0.64 & 20.77 & 3.68 & 0.81 \\
\hline
\end{tabular}


2.3. Instrumentation. Pullout tests were performed using a universal testing machine (UTM). Linear variable differential transducers (LVDTs) were used to measure the bar displacement. Two LVDTs were used on the loaded end whereas one was fixed at the unloaded end. The test setup is shown in Fig. 2. The load was applied at a rate of $3 \mathrm{kN} / \mathrm{s}$ on the bar, and the data of applied load and slip were constantly recorded through a data acquisition system. Concrete strength on the day of testing and SD are given in Table 4, which results are averaged from the data on 3 cylinders.

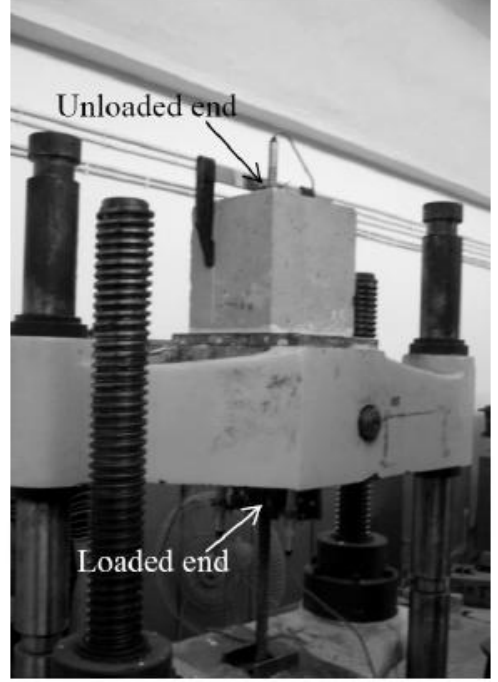

a

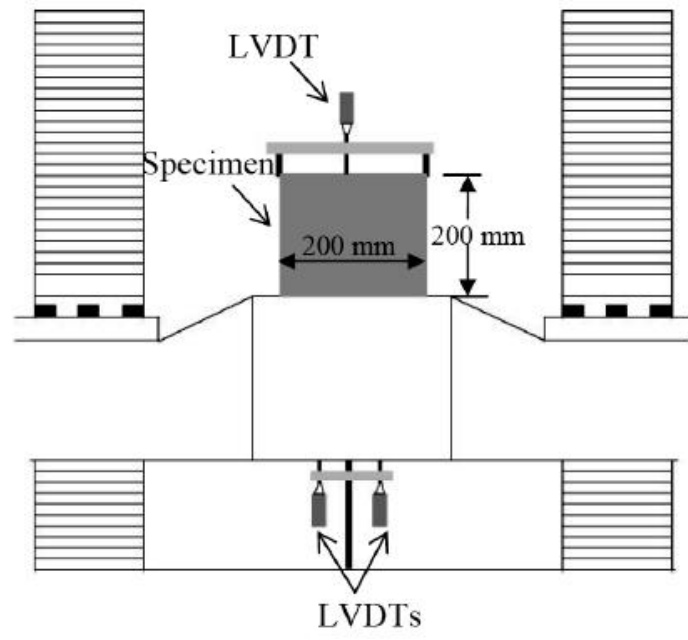

$\mathrm{b}$

Fig. 2. Setup of pullout test: (a) lab specimen; (b) schematic arrangement.

3. Results and Discussion. The relative displacement between the loaded end of the bar and the concrete is referred as loaded-end slip whereas the relative displacement between the rebar free-end and the concrete is referred to as the free-end slip in the forthcoming discussion. The results in the forthcoming sections are based on an average of three pullout specimens.

3.1. Failure Mode. All tested specimens typically exhibited the bond failure after the concrete in front of bar lugs (ribs) was crushed and the bar was pulled out. Figure 3 shows view of some of the failed specimens along with the pulled out bars and a schematic of the failure mechanism. This behavior was the same for all specimens and was irrespective of the bar type (hot-rolled or cold-twisted) and diameter, and the type of concrete mix.

Figure 4 illustrates representative plots of data of slip $(s)$ for the loaded and free ends of the bar versus the interfacial bond stress. The slip in the bar is a result of stress-strain compatibility requirements between steel and concrete which are, respectively, in tension and compression due to the applied force. It is noted in Fig. 4 that the free-end slip precedes the loaded-end slip for all the specimens. These plots are typical for other bar diameter and type, and the concrete type (Table 3). Possible factors to cause this difference include initial settling of specimen on the plate, play in the support of LVDTs, elongation of bar and wedging of concrete into indentations of the bar. Further, a considerably long descending branch is seen in Fig. 4 without sudden failure, after the maximum interfacial bond stress $\left(\tau_{\max }\right)$ is reached; this indicates a ductile bond failure for all the specimens included in the testing program. This descending branch is a result of the resistance offered by the frictional component of bond beyond the maximum bond strength. Note that the adhesion is generally lost at low values of bar slip. 


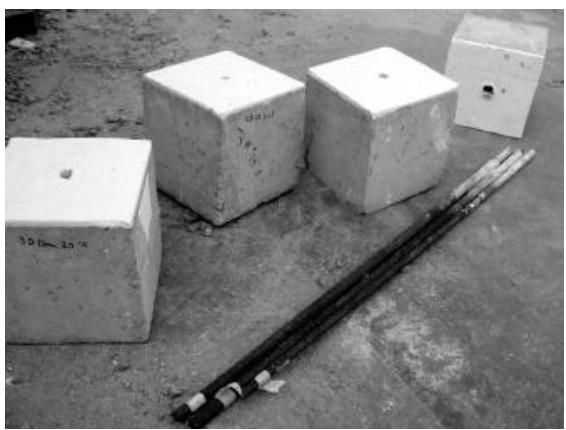

a
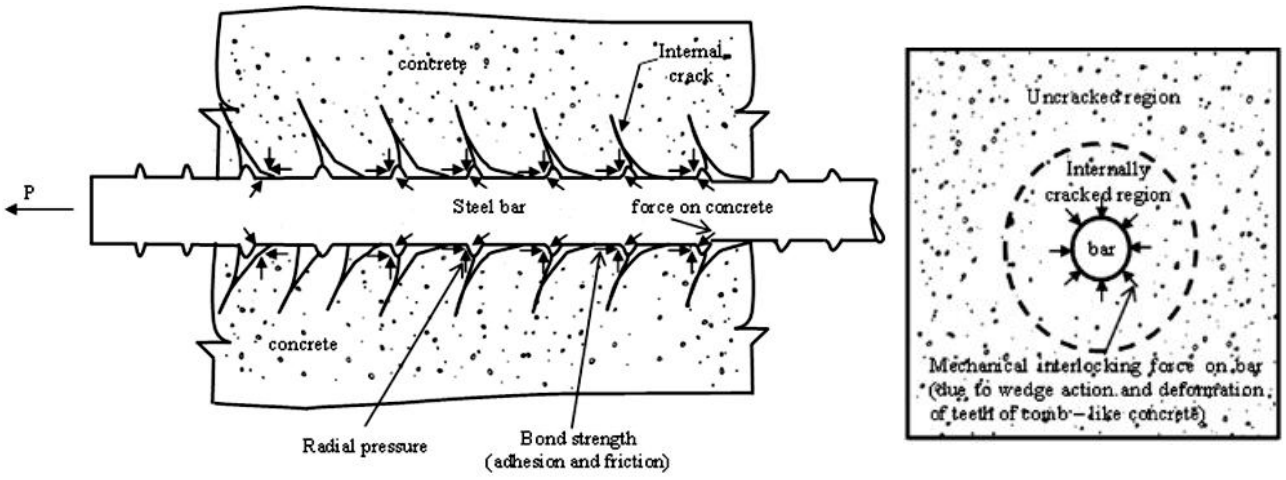

b

Fig. 3. View of failed pullout specimens (a) and schematic of failure mechanism [46] (b).

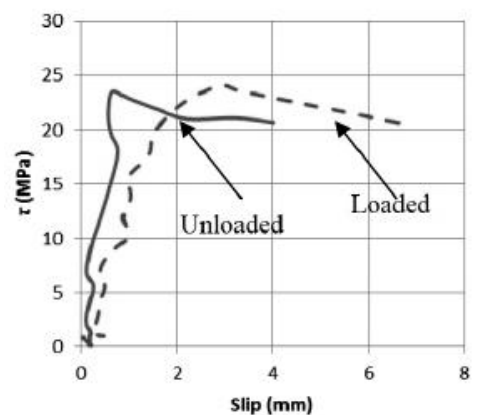

a

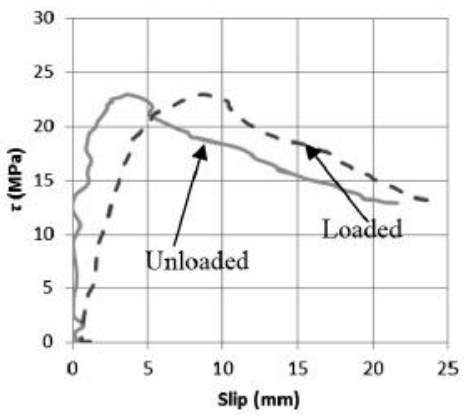

c

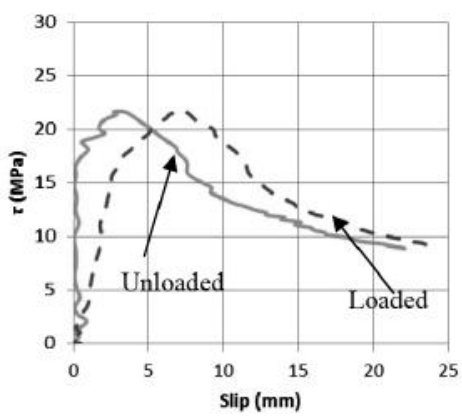

$\mathrm{b}$

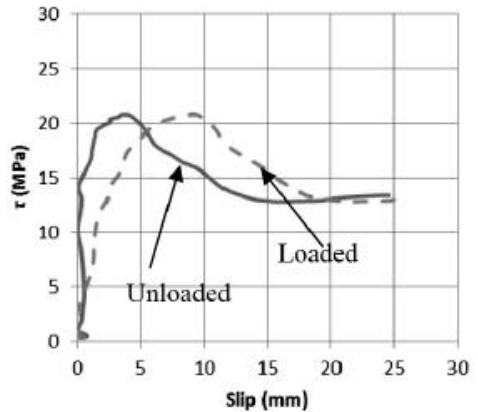

d

Fig. 4. Free-end versus loaded-end slip: (a) 0P12D; (b) 10P16D; (c) 20P16T; (d) 30P20T. 

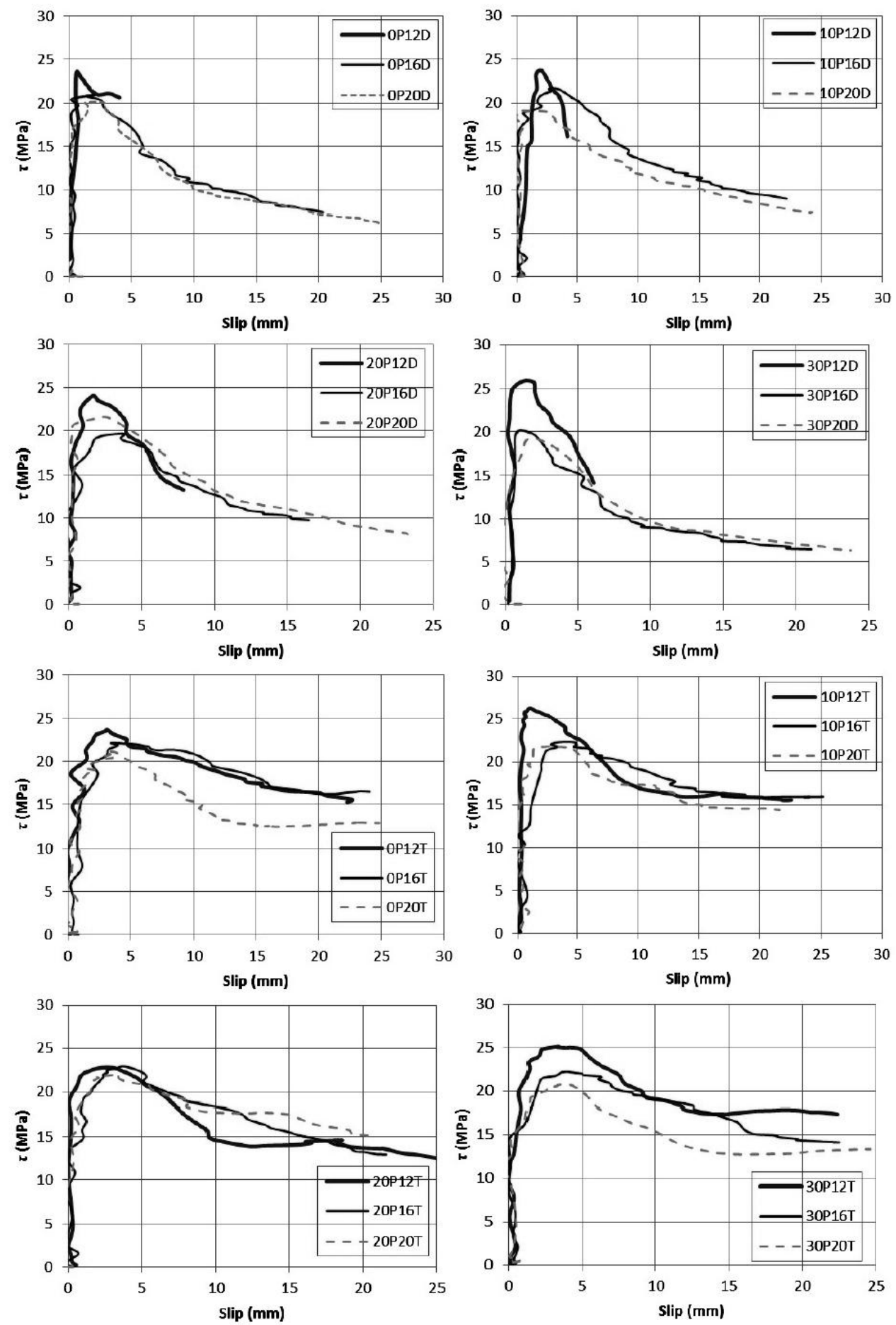

Fig. 5. Comparison of pullout behavior of different diameter bars.

3.2. Effect of Bar Diameter. Figure 5 illustrates the effect of bar diameter on the interfacial bond stress of the rebar. The data of the unloaded ends of the bars have been reported in Fig. 5 and in the forthcoming sections. The results of both the hot-rolled 

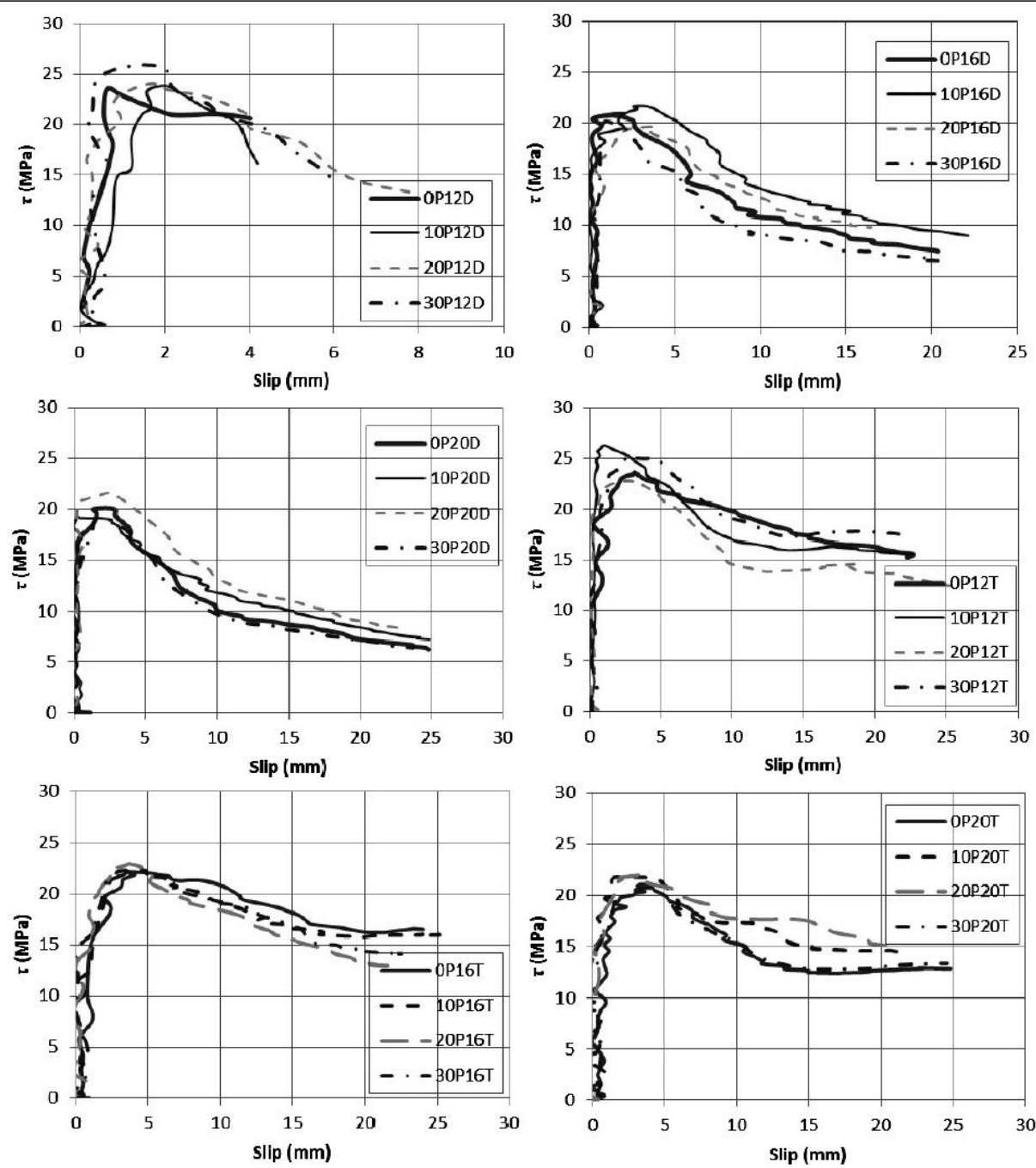

Fig. 6. Effects of concrete type on interfacial bond stress-slip behavior.

deformed and cold-twisted ribbed bars have been included in Fig. 5. It is seen in Fig. 5 that the $12 \mathrm{~mm}$ bar offers higher resistance to slip as compared to the other diameter bars (16 and $20 \mathrm{~mm}$ ). As a result, the interfacial bond strength is higher for specimens employing 12 $\mathrm{mm}$ diameter bars. The observed bond stress is maximum for the specimens 30P12D and 10P12T (Table 4). The interfacial bond stress decreases with increase in the bar diameter and the specimens with 16 and $20 \mathrm{~mm}$-diameter bars exhibited lower interfacial bond stress. This can be explained due to closely spaced ribs for $12 \mathrm{~mm}$ bars (average distance of $7.2 \mathrm{~mm}$ ), as compared to 16 and $20 \mathrm{~mm}$-diameter bars, which had average rib distance of 8.9 and $9.7 \mathrm{~mm}$, respectively. As a result, $12 \mathrm{~mm}$-diameter bars possessed better friction and adhesion properties that increased the bond strength between the bar and the concrete. Note that the rib spacing was measured using the tested bars between two successive ribs along the same horizontal line on the bar circumference and an average of three measurements was used. The same method was followed for both the hot-rolled deformed and cold-twisted ribbed bars. Further, it is seen in Fig. 5 that the specimens made with $12 \mathrm{~mm}$-diameter hot-rolled deformed bars exhibited less ductile behavior in the post-peak region of bond stress-slip curve with a short descending branch. The length of descending 
branch increased with the bar diameter. This can be attributed to better bearing on the lugs provided by the 16 and $20 \mathrm{~mm}$-diameter bars, which had an average height of lugs of $1.1 \mathrm{~mm}$, as compared to $0.83 \mathrm{~mm}$ lug height for the $12 \mathrm{~mm}$-diameter bars. For cold-twisted ribbed bars, the post-peak ductility of the interfacial bond is similar for all bars and all specimens provided nearly the same level of ductility.

3.3. Effect of Concrete Type. Figure 6 presents a comparison of influence of RAC on the interfacial bond stress-slip behaviors of the bars. It is seen in Fig. 6 that the behavior of bar is similar for control specimens and those made with RCA replacement. Similar pre-peak response, $\tau_{\max }$ and post-peak behavior of the bond characteristics of the bar of each diameter and type are seen in these plots. Xiao and Falkner [30] and Prince and Singh $[28,34]$ also reported similar bond strength with specimens made with and without addition of RCA. On the other hand, Butler et al. [31] found up to $19 \%$ lesser bond strength in pullout specimens made with RCA. The values of $\tau_{\max }$ for the bars with each of the employed concrete types are given in Table 4. It can be noted in Table 4 that the differences in $\tau_{\max }$ are quite small (within 10\%) and, thus, are negligible.

3.4. Effect of Bar Type. Figure 7 presents a comparison of bond-slip behaviors of the hot-rolled deformed and cold-twisted ribbed bars. It is noted in Fig. 7 that both type of bars attained similar $\tau_{\max }$ at all levels of RCA replacement which was similar to the control specimen. In general, the cold-twisted ribbed bars showed higher ductility in the post-peak region with a long descending branch as compared to the hot-rolled deformed bars. This may be partly attributed to better bearing on the lugs provided by cold-twisted ribbed bars to the bond strength, which increased the frictional resistance of these bars to the bond failure. The difference is more significant for smaller diameter bars and disappears as the bar diameter is increased. As a result, the specimens made with $20 \mathrm{~mm}$ bars showed nearly the same maximum slip for both the hot-rolled deformed and cold-twisted ribbed bars before failure. In addition, the cold-twisted ribbed bars offered higher frictional resistance to reduce the amount of slip in the post-peak region, as compared to the hot-rolled deformed bars. This resulted in a stiffer post-peak bond stress-slip response of the cold-twisted bars.

3.5. Interfacial Bond Strength. Figure 8 depict the normalized stress versus the bar diameter curves. Here the maximum interfacial bond stress was normalized by $\sqrt{f_{c}}$. It is seen in Fig. 8 that the normalized stress decreases with the bar diameter. As a result, the 12 $\mathrm{mm}$-diameter bar has the highest normalized stress. The change in this stress between 16 and $20 \mathrm{~mm}$-diameter bar is nominal. The behavior of both hot-rolled deformed and cold-twisted ribbed bars are the same in this respect. The effects of concrete type on the normalized stress are also seen in Fig. 8. In general, the normalized stress reduces with the level of RCA replacement. Table 4 provides the data of bond ratio, which is the ratio of normalized bond of the bars embedded in RAC specimens to that of the control ones. It is seen in Table 4 that the difference in the bar interfacial bond strength with most of the RAC specimens is within $15 \%$, as compared to the control ones.

Conclusions. This paper reported studies related to the bond tests of the steel bars. The bond behaviors of hot-rolled deformed and cold-twisted ribbed bars with RAC was investigated using concentric pullout specimens. Three levels of RA replacement in RAC were employed. The diameter of bars included 12, 16, and $20 \mathrm{~mm}$. The embedment length of the bar was taken as $5 d_{b}$. Specimens made from natural aggregate concrete were used as control specimens. The following conclusions have been drawn from the studies presented.

1. All pullout specimens failed by pullout mode of bond failure, which was the expected failure mode. The failure was caused by the pulling of the bar after a significantly larger rebar slip. Smaller diameter bars demonstrated higher interfacial bond strength due to closer ribs in these bars. The bond strength decreased as the bar diameter was increased. This can be attributed to increased rib spacing in the larger diameter rebars. 

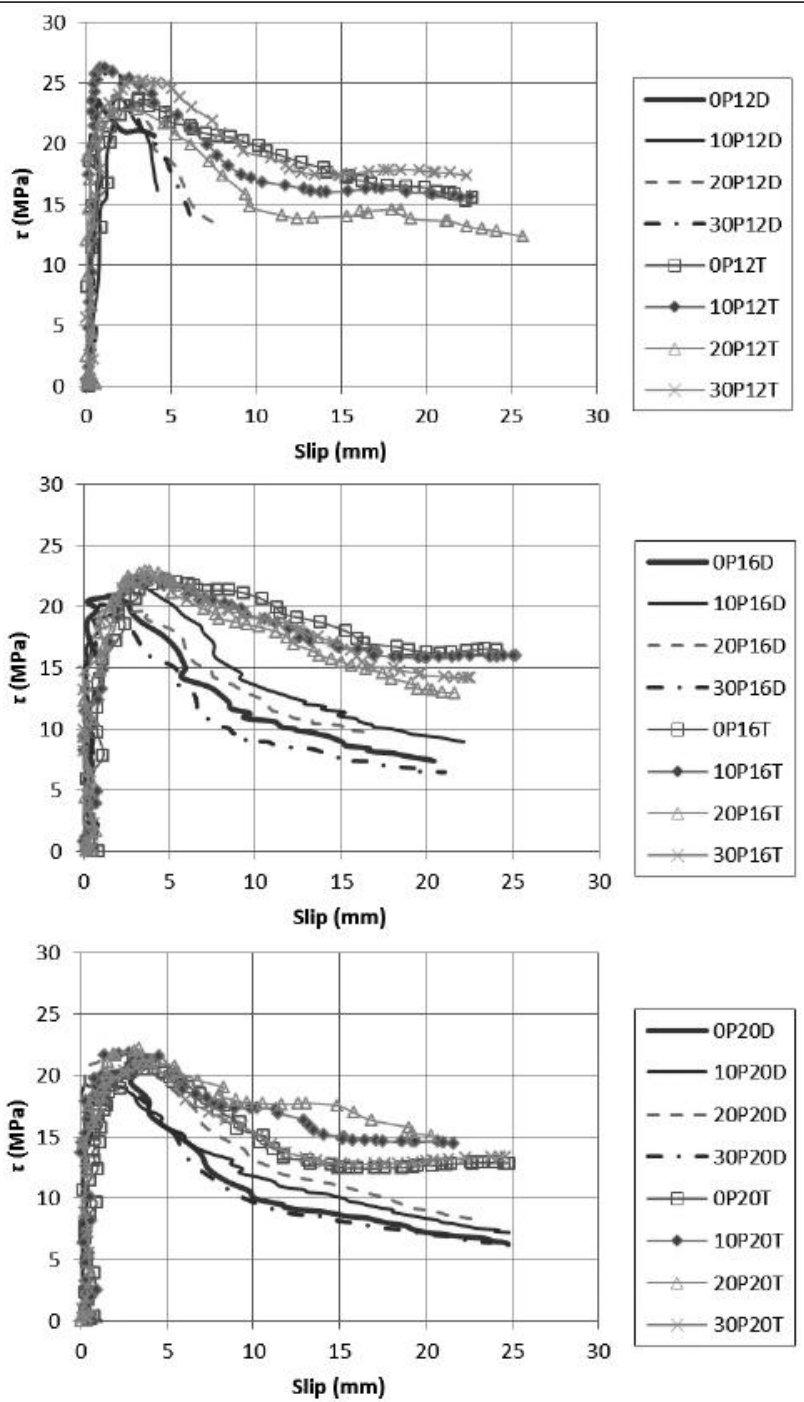

Fig. 7. Effect of bar type on interfacial bond stress-slip behavior.

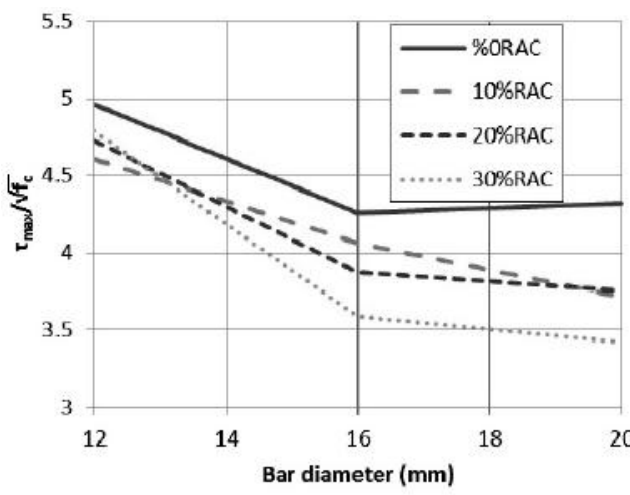

a

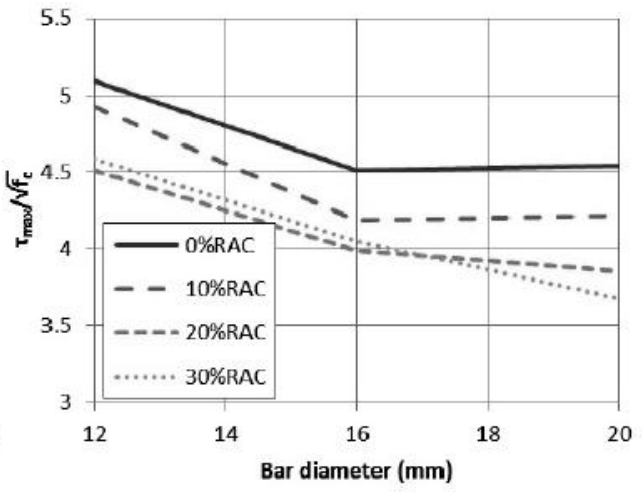

b

Fig. 8. Normalized interfacial bond stress versus bar diameter: (a) hot-rolled deformed bars; (b) coldtwisted ribbed bars. 
2. The bond behavior of a particular diameter bar was unaffected by the replacement of RA in concrete and was similar to the control specimen. These are significant results which indicate that the bond behavior of RAC remains similar as the concrete made with virgin aggregates. Most of the bars achieved up to 85 percent of normalized bond strength $\left(\tau_{\max } / \sqrt{f_{c}}\right)$ in RAC, as compared to the concrete made from natural aggregates.

3. The bond stress-slip response of both the hot-rolled deformed and cold-twisted ribbed bars was similar in the ascending part of the curve. The bond characteristics of the hot-rolled deformed bars indicated lesser ductility in the descending portion of the observed bond stress-slip envelope as compared to the cold-twisted ribbed bars. This indicates that the indentations on the cold-twisted ribbed bars provide better friction resistance to bond, as compared to that of hot-rolled deformed bars.

4. Although the pullout specimens with different bar types and sizes, concrete strength and level of RCA addition were used for the findings and suggestions made in this study, these apply only to bars with the embedment length not exceeding $5 d_{b}$.

\section{Резюме}

Переробка бетону є одним з ефективних розв'язків проблеми утилізації будівельних відходів. Досліджується зміна адгезійних напружень на стику стальних арматурних стрижнів із матрицею з переробленого бетону залежно від величини проковзування між ними. Адгезійні випробування на розтяг проводились на концентричних зразках. Зразки з наповнювачем зі стандартного бетону використовували як контрольні. Досліджувались арматурні стрижні двох типів (гарячекатані деформовані і холоднокручені ребристі) із різним діаметром і різною долею домішки переробленого бетону. Довжина защемлення стрижнів у п'ять разів перевищувала їх діаметр. Стрижні діаметром 12 мм мали найвищу міцність міжфазового зчеплення/адгезії, яка зменшувалась зі збільшенням їх діаметра. Величина долі домішки переробленого бетону практично не впливала на адгезійну міцність стрижнів. При цьому реакція холоднокручених ребристих стрижнів після досягнення піка адгезійних напружень залежно від проковзування є більш жорсткою, ніж гарячекатаних деформованих стрижнів.

1. H. Goldstein, "Not your father's concrete," Civil Eng., 65, No. 5, 60-63 (1995).

2. T. Park, "Application of construction and building debris as base and sub-base materials in rigid pavement," J. Transp. Eng., 129, No. 5, 558-563 (2003).

3. A. Topal, A. U. Ozturk, and B. Baradan, "Use of recycled concrete aggregates in hot-mix asphalt," SP-235-20 (2006), pp. 291-304.

4. S. Paranavithana and A. Mohajerani, "Effects of recycled concrete aggregates on properties of asphalt concrete," Resour. Conserv. Recy., 48, No. 1, 1-12 (2006).

5. S. D. Ramaswamy and M. A. Aziz, "Some waste materials in road construction," in: Utilization of Waste Materials in Civil Engineering Construction, ASCE, New York (1992), pp. 153-165.

6. A. R. Chini and F. M. B. R. Monteiro, "Use of recycled aggregate as a base course," in: Proc. of the 35th Annual Conference, Associated Schools of Construction California Polytechnic State University - San Luis Obispo, CA (1999), pp. 307-318.

7. B. Melbouci, "Compaction and shearing behavior study of recycled aggregates," Constr. Build. Mater., 23, No. 8, 2723-2730 (2009).

8. S. M. Levy and P. Helene, "Durability of recycled aggregates concrete: a safe way to sustainable development," Cement Concrete Res., 34, No. 11, 1975-1980 (2004). 
9. N. D. Oikonomou, "Recycled concrete aggregates," Cement Concrete Comp., 27, No. 2, 315-318 (2005).

10. G. R. Robinson, Jr., W. D. Menzie, and H. Hyunc, "Recycling of construction debris as aggregate in the Mid-Atlantic region, USA," Resour. Conserv. Recy., 42, No. 3, 275-294 (2004).

11. R. Teha, A. Al-Rawas, K. Al-Jabri, et al., "An overview of waste materials recycling in the Sultanate of Oman," Resour., Conserv. Recy., 41, No. 3, 293-306 (2004).

12. Y. Huang, R. N. Bird, and O. Heidrich, "A review of the use of recycled solid waste materials in asphalt pavements," Resour. Conserv. Recy., 52, No. 1, 58-73 (2007).

13. U. Mroueh, and M. Wahlstram, "By-products and recycled materials in earth construction in Finland: an assessment of applicability," Resour. Conserv. Recy., 35, Nos. 1-2, 117-129 (2002).

14. Y. D. Wong, D. D. Sun, and D. Lai, "Value-added utilization of recycled concrete in hotmix asphalt," Waste Manage., 27, No. 2, 294-301 (2007).

15. R. E. Untrauer and R. L. Henry, "Influence of normal pressure on bond strength," $J$. Am. Concrete I., 62, No. 5, 577-586 (1965).

16. M. M. Rafi, S. H. Lodi, and A. Nizam, "Chemical and mechanical properties of steel rebars manufactured in Pakistan and design implications," J. Mater. Civil Eng., 26, No. 2, 338-348 (2014).

17. BS 4449: 2005. Steel for the Reinforcement of Concrete Weldable Reinforcing Steel, Bar, Coil and Decoiled Product, British Standards Institution, London (2005).

18. ASTM A615/A615M-16a. Standard Specification for Deformed and Plain CarbonSteel Bars For Concrete Reinforcement, ASTM International, West Conshohocken, PA (2016).

19. A. Ajdukiewicz and A. Kliszczewicz, "Comparative tests of beams and columns made of recycled aggregate concrete and natural aggregate concrete," J. Adv. Concr. Technol., 5, No. 2, 259-273 (2007).

20. G. Fathifazl, G. A. Razaqpur, B. O. Isgor, et al., "Shear capacity evaluation of steel reinforced recycled concrete (RRC) beams," Eng. Struct., 33, No. 3, 1025-1033 (2011).

21. I. S. Ignjatović, S. B. Marinković, Z. M. Mišković, and A. R. Savić, "Flexural behavior of reinforced recycled aggregate concrete beams under short-term loading," Mater. Struct., 46, No. 6, 1045-1059 (2013).

22. B. González-Fonteboa and F. Martinez-Abella, "Shear strength of recycled concrete beams," Constr. Build. Mater., 21, No. 4, 887-893 (2007).

23. A. M. Knaack and Y. C. Kurama, "Design of concrete mixtures with recycled concrete aggregates," ACI Mater. J., 110, No. 5, 483-493 (2013).

24. J. Pacheco, J., J. de Brito, J. Ferreira, and D. Soares, "Destructive horizontal load tests of full-scale recycled-aggregate concrete structures," ACI Struct. J., 112, No. 6, 815826 (2015).

25. M. Arezoumandi, A. Smith, J. S. Volz, and K. H. Khayat, "An experimental study on flexural strength of reinforced concrete beams with $100 \%$ recycled concrete aggregate," Eng. Struct., 88, 154-162 (2015).

26. F. Soleimani, M. McKay, C. S. W. Yang, et al., "Cyclic testing and assessment of columns containing recycled concrete debris," ACI Struct. J., 113, No. 5, 1009-1020 (2016).

27. A. P. Clark, "Bond of concrete reinforcing bars," J. Am. Concrete I., 46, No. 11, 161-184 (1949). 
28. M. J. R. Prince and B. Singh, "Investigation of bond behavior between recycled aggregate concrete and deformed steel bars," Struct. Concrete, 15, No. 2, 154-168 (2014).

29. G. Metelli and G. A. Plizzari, "Effects of relative rib area on bond behavior," Stud. Res., 27, 141-163 (2007).

30. J. Xiao and H. Falkner, "Bond behavior between recycled aggregate concrete and steel rebars," Constr. Build. Mater., 21, 395-401 (2007).

31. L. Butler, J. S. West, and S. L. Tighe, "The effect of recycled concrete aggregate properties on the bond strength between RCA concrete and steel reinforcement," Cement Concrete Res., 41, 1037-1049 (2011).

32. S. W. Kim and H. D. Yun, "Influence of recycled coarse aggregates on the bond behavior of deformed bars in concrete," Eng. Struct., 48, 133-143 (2013).

33. C. Lima, A. Caggiano, C. Faella, et al., "Physical properties and mechanical behavior of concrete made with recycled aggregates and fly ash," Constr. Build. Mater., 47, 547-559 (2013).

34. M. J. R. Prince and B. Singh, "Pullout behavior of deformed steel bars in highstrength recycled aggregate concrete," Proc. ICE - Constr. Mater., 169, No. 1, 13-26 (2016).

35. K. Choi, Anchorage of Beam Reinforced at Conventional and Fibrous Beam-Column Connections, PhD Thesis, Michigan State University, USA (1988).

36. ASTM C127-01. Standard Test Method for Density, Relative Density (Specific Gravity), and Absorption of Coarse Aggregate, ASTM International, West Conshohocken, PA (2001).

37. ASTM C-128-01. Standard Test Method for Density, Relative Density (Specific Gravity), and Absorption of Fine Aggregate, ASTM International, West Conshohocken, PA (2001).

38. ASTM C29/C29M-97. Standard Test Method for Bulk Density (Unit Weight) and Voids in Aggregate, ASTM International, West Conshohocken, PA (1997).

39. ASTM C136-01. Standard Test Method for Sieve Analysis of Fine and Coarse Aggregates, ASTM International, West Conshohocken, PA (2001).

40. ASTM C131/C131M0-14. Standard Test Method for Resistance to Degradation of Small-Size Coarse Aggregate by Abrasion and Impact in the Los Angeles Machine, ASTM International, West Conshohocken, PA (2014).

41. ASTM C33-03. Standard Specification for Concrete Aggregates, ASTM International, West Conshohocken, PA (2003).

42. ASTM C150-04. Standard Specification for Portland Cement, ASTM International, West Conshohocken, PA (2004).

43. ASTM E8/E8M-16. Standard Test Methods for Tension Testing of Metallic Materials, ASTM International, West Conshohocken, PA (2016).

44. "RC 6 Bond test for reinforcement steel. 2. Pull-out test, 1983," in: RILEM Recommendations for the Testing and Use of Constructions Materials, RILEM (1994), pp. 218-220.

45. ACI 211.1-91: Standard Practice for Selecting Proportions for Normal, Heavyweight and Mass Concrete (Reapproved 2009), ACI Committee 2011 (1991).

46. Y Goto, "Cracks formed in concrete around deformed tension bars," ACI Struct. J., 68, No. 4, 244-251 (1971). 